\title{
Biodiversity management plan in the non-conservation area, Cisokan hydropower plan area, Cianjur, West Java, Indonesia
}

\author{
TEGUH HUSODO ${ }^{1,2,3}$, SYA SYA SHANIDA ${ }^{1,3, \boldsymbol{p}}$, ERRI NOVIAR MEGANTARA ${ }^{1,2,3}$ \\ ${ }^{1}$ Department of Biology, Faculty of Mathematics and Natural Sciences, Universitas Padjadjaran. Jl. Raya Bandung-Sumedang Km 21, Jatinangor, \\ Sumedang 45363, West Java, Indonesia. \\ ${ }^{2}$ Program of Environmental Science, School of Graduates, Universitas Padjadjaran. Jl. Sekeloa, Coblong, Bandung 40134, West Java, Indonesia. \\ ${ }^{3}$ Institute of Ecology, Directorate of Research, Community Services and Innovation, Universitas Padjadjaran. J1. Raya Jatinangor Km 21, Sumedang \\ 45363, West Java, Indonesia. Tel-Fax +62-22-7796412. ”email: syasyashanida@gmail.com
}

Manuscript received: 3 October 2018. Revision accepted: 6 May 2019.

\begin{abstract}
Husodo T, Shanida SS, Megantara EN. 2019. Biodiversity management plan in the non-conservation area, Cisokan hydropower plan area, Cianjur, West Java, Indonesia. Biodiversitas 20: 1524-1536. Based on data from various environmental studies at the Upper Cisokan Pumped Storage (UCPS) Hydropower plan area, further studies need to be carried out that can provide clearer guidance on how to protect and restore the environment (including habitat) around the UCPS, protect, and manage the endangered biodiversity through adaptive approaches and ecosystem management. One of these studies was the UCPS Biodiversity Management Plan (BMP). The aim of this study was to identify the strategy for biodiversity management at the project site. Methods of this study were based on several years of qualitative and descriptive-analytical studies, which updated information from earlier studies. Information on the area's biodiversity was obtained directly through field surveys and indirectly through semi-structured interviews and focus group discussions (FGD) with local community members and other stakeholders in the area. This article presents the strategy for biodiversity management at project site, including minimizing habitat gap and habitat loss; expanding and enriching habitats; making corridors; protecting the natural forests (protection of remnant forest); controlling access; managing fire, the impact of traffic on native fauna, land clearing and human-wildlife conflict; minimizing impacts to biodiversity, particularly threatened species; integrating management with adjoining land managers (PLN, perhutani, the community); strengthening capacities for integrating and institutionalizing biodiversity conservation and management; conducting campaign for biodiversity awareness, communication, and education; and developing value-added products and alternative sustainable livelihood for bio-resource-dependent communities.
\end{abstract}

Keywords: Biodiversity Management Plan, Cisokan, hydropower

Abbreviations: PLN: the Indonesian State-owned power company; UCPS: Upper Cisokan Pumped Storage; BMP: Biodiversity Management Plan; FGD: focus group discussion; Perhutani: an Indonesian state-owned forest company; LIPI: Indonesian Institute of Sciences; ANDAL: Environmental impact analysis; NGO: non governmental organization; BIA: biodiversity-important area; SOP: standard operating procedure; TNI: Indonesian national army.

\section{INTRODUCTION}

PT PLN (Persero) (PLN), the Indonesian State-owned power company, is in the final stages of preparing to start construction of the Upper Cisokan Pumped Storage (UCPS) Hydropower Scheme. The project will be a 1040 MW pumped-storage hydropower scheme on the Cisokan and Cirumanis Rivers, West Java, Indonesia. PLN is committed to sustainability and consistently seeks to put the economic, social and environmental performances in the balance as a manifestation of the 'triple bottom lines' philosophy, in order to make sustainable business growth (PLN 2012). This also includes a commitment to biodiversity with their environmental policy aiming to prevent environmental pollution and biodiversity degradation in company operation areas, for example through participation in reforestation programs in the watershed where the company works.

Biodiversity can be a factor in project risk management. Non-technical risks can be the major reasons for delays in extractive industry project and social conflicts related to environmental resources is usually the main factor.
Integrating biodiversity risk management into the company's decision-making process from the beginning of the project is key to reducing downstream operational and financial risks, and therefore, it makes sense from a business point of view (Australian Government 2016).

According to the data from various environmental studies at the UCPS Hydropower plan area, Cisokan has high biodiversity such as endemic species and endangered species within the UCPS hydropower area. The construction of UCPS hydropower can certainly cause disruption to local biodiversity, especially several species that have important conservation status. This is caused by the loss and/or fragmentation of habitat including the disruption of wildlife mobility. Continuing habitat fragmentation will cause the extinction of local species. According to a study based on 2.382.624 records on ecological diversity worldwide, two-thirds of vertebrates (compared to that in 1970), including many species of mammals, birds, and fish, could disappear by 2020 (Dittmar 2014; Newbold et al. 2016).

Until now, various biodiversity conservation efforts are still focused on natural ecosystems such as forests. There has not been much research on biodiversity carried out 
specifically in the non-conservation areas, even though many regions in Indonesia have extensive community lands and are directed to be areas that have a conservation function, besides still functioning as a production system. Therefore, it is necessary to make efforts to manage biodiversity that is still found in the project site and its surroundings, especially monitoring wildlife that has important conservation status.

Further studies need to be carried out that can provide clearer guidance on how to protect and restore the environment (including habitat) around the UCPS, protect, and manage the endangered biodiversity through adaptive approaches and ecosystem management. One of the studies was the UCPS Biodiversity Management Plan (BMP). The BMP provides a strategy and an action plan for biodiversity management at the project site and around it, so the aim of this study was to identify the strategy for biodiversity management at the project site. The results of this study are presented in this article. According to BHP Billiton (2017), the biodiversity management plan has been prepared to provide a consistent and standard approach to the management of significant flora. It has been developed in consideration of the legal requirements relevant to native flora. BMP document preparation referred to all relevant project standards and legal requirements. To obtain optimal results and adapt to environmental changes that occur, the BMP will be reviewed periodically, also following consultation with relevant stakeholders.

\section{MATERIALS AND METHODS}

\section{Study area}

This study is located on the border between West Bandung and Cianjur, and around the Cisokan River, West Java, Indonesia. The location is in Cipongkor, Rongga, Bojongpicung, Cempaka, and Cibeber Sub-district. The project is located in the upstream catchment area of the Cisokan River on a ridge stretching from west to east of Java, the most densely populated island in the Indonesian Archipelago. The Cisokan River generally flows from the south to the north as a tributary of the Citarum, which flows into the Java Sea on the northern coast of Java. The Citarum River is the largest river on the island of Java and has a number of hydropower plants along the river; the closest hydroelectric power plant from Upper Cisokan Hydroelectric Power Plant is Cirata and Saguling (LPPM-PPSDAL UNPAD 2014). The area is divided into seven land use types, namely natural forests/remnant forests, production forests (including Pinus spp., Tectona grandis), irrigated rice fields, swidden cultivations/ huma, shrubs, mixed gardens/talun, and settlements. The figure below is the map of the UCPS location showing where various developments will take place (Figure 1).

The site plan for the UCPS consists of: (i) development of the main construction (powerhouse, surge tank, switchyard, upstream dam, and downstream dam); (ii) access road $(27.5 \mathrm{~km})$; (iii) inundation area includes upstream and downstream inundation; (iv) transmission lines and quarries and potentially landslides areas.

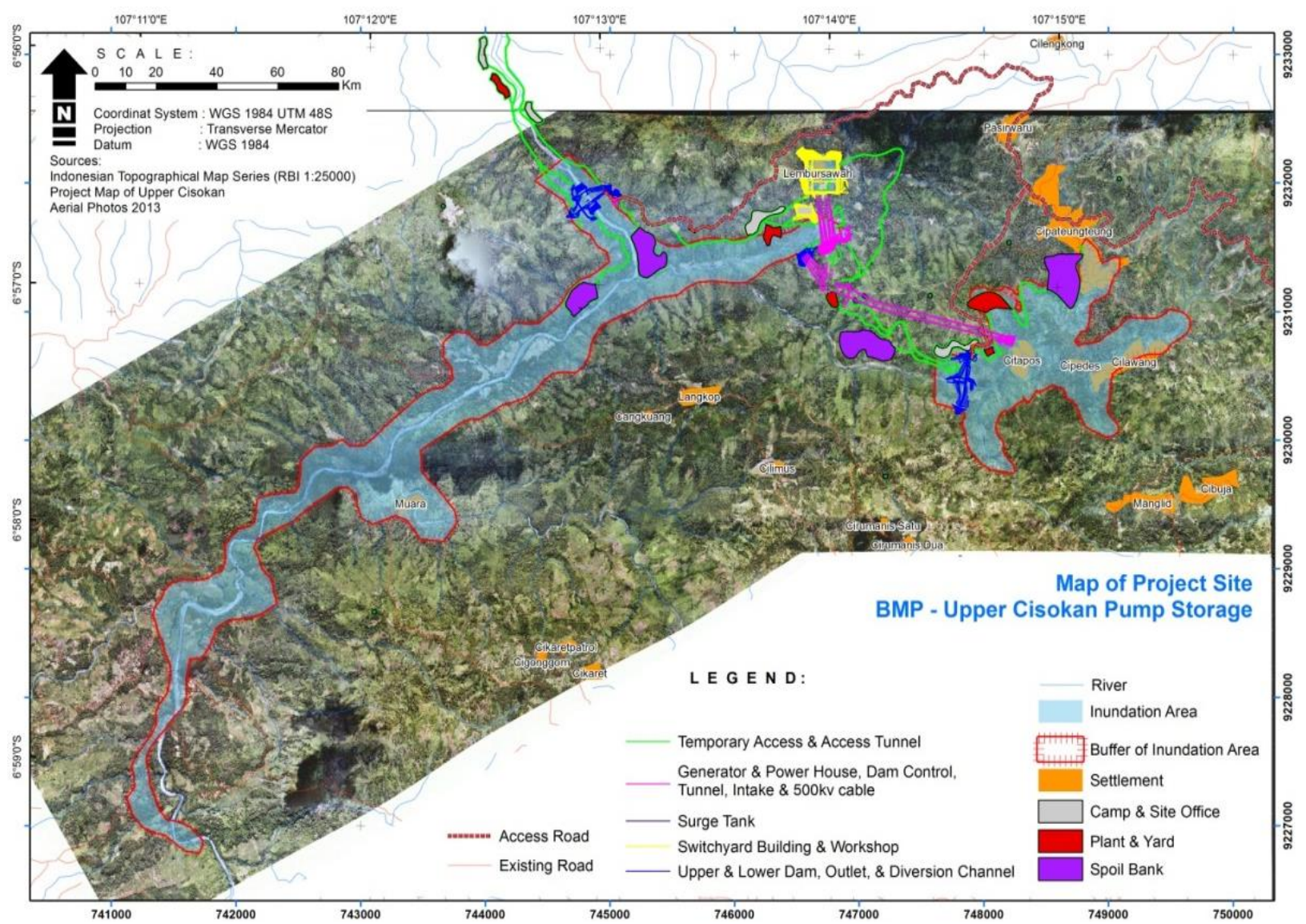

Figure 1. Location map of the project site in Upper Cisokan Pumped Storage (UCPS), Cianjur, West Java, Indonesia (48 M 746030.02 m E $9231551.58 \mathrm{~m} \mathrm{~S}$ ) (in 2014) 


\section{Procedures}

The BMP compilation was carried out through qualitative method. Primary data collections were carried out in this study, including semi-structured interviews with informants (e.g. local elders, poachers, and farmers) selected using purposive sampling, survey of flora and 10 species of protected animals (survey of several species of animals using sign survey and installation of camera traps), and FGD with some stakeholders, such as staff of PLN, Perhutani (state-owned forest company), local people, and NGOs. Secondary data used in this study were reports of ANDAL (2007); PLN (2011); PLN (2012); Rahmat (2009); and LIPI (2012).

The most common ways in stakeholder analysis are through focus group discussions (FGD), interviews, and workshops. Ardhian (2007) used discussion methods with project implementers and interviews that can provide complete information of stakeholders at the project site. Interviews with key informants are needed to complete the information, as well as the cross-checking process to make the information more accurate.

The BMP compilation referred to Documents and Options (Issues and Options) that had been prepared beforehand. These documents were related to the aspects that affect the biodiversity, and the problems caused by the project were the main issues due to the activities of the UCPS. Management direction was needed to minimize the impact/issues that arise. Furthermore, these documents were sorted to focus on threats to biodiversity and formulate management steps that need to be done.

The data on 10 protected animal species were collected through surveys and presented according to species, age, gender, and group hierarchy (if any) to identify each individual and group. Species identification was done using guidebooks by Francis (2001) and Payne and Francis (2000). Identification of species obtained through sign surveys was carried out by collecting species based on morphometrics, age, and location characteristics on feces, footprints, hair, nests, etc. Identification of footprints was done using guidebooks by van Strien (1983), Atmoko et al. (2012) and Payne and Francis (2000). The identification of images captured through camera trap was carried out by species collection data using the guidebooks of Francis (2001) and Payne and Francis (2000), and identification was carried out at the individual level based on number, morphology, and body motives (e.g., Javan Leopard and Leopard Cat). Social aspects such as semi-structured interviews and FGDs were conducted through crosschecking, summarizing, synthesizing, and narrative accounts sequentially (Newing et al. 2011).

\section{Data analysis}

The data were analyzed qualitatively.

\section{RESULTS AND DISCUSSION}

\section{Landscapes and biodiversity of Cisokan Major habitat}

To delineate the main vegetation types in Cisokan, we combined the results of biodiversity research conducted by the Indonesian Institute for Sciences/LIPI (2012), as well as earlier studies by Rahmat (2009), and the ANDAL UCPS hydropower study (2007), with the results of the analysis of RapidEye imagery maps 2011-2012. The analysis identified several ecosystem types (or vegetation communities), including remnant forests, production forests (with stands of pine, teak, or Altingia excelsa), mixed gardens or agroforestry (locally named as talun), shrubs, slash and burn cultivation areas that make up agricultural fields on slopes, rice fields in flat areas, and fish ponds, settlements and yards.

\section{Natural forests}

LIPI (2012) and Rahmat (2009) recorded at least 376 species of plants belonging to 268 genera and 160 families in the area of natural forest in UCPS hydropower project site and surrounding areas. From the 160 families recorded, the dominant families that make up the forest community include Euphorbiaceae (22 species), Moraceae (21 species), Meliaceae (15 types), and Fabaceae (23 species). These areas generally have the highest biodiversity.

\section{Mixed gardens/talun/agroforestry}

This system is also known as community forest and encompasses a variety of crops and plants. Some of the dominant plant species in this ecosystem type are sugar palm (Arenga pinnata), timber species such as Albizia falcataria, Paraserianthes sp, and mahogany (Swietenia mahogany), as well as a range of fruit trees for human consumption, including soursop (Annona muricata), menteng (Baccaurea racemosa), rambutan (Nephelium lappaceum), and mango (Mangifera indica). Some of the plant species here have high economic value such as durian (Durio zibethinus) and petai (Parkia speciosa). These areas can be quite valuable for biodiversity, depending on species composition, size of the area, and also threats such as hunting.

\section{Shrubs and upland vegetations}

These ecosystem types can be found along the Cirumamis River, Cilengkong River and on the east side of the Cisokan River, especially on slopes. Although the status of these areas is in many cases are protected area within the production forest, the areas are quite degraded because of illegal timber extraction, the collection of grass for animal feed and other resource extraction. This is also evident in the production forests to the west of the Cisokan River where communities have trees such as Albizia falcataria, teak (Tectona grandis) and Calliandra calothyrsus. Local communities also utilize these upland scrub areas and fields for slash and burn cultivation, often using annual crops for cultivation understands of trees that had been planted earlier. These cultivated land systems contain lemongrass (Andropogon citratus), mixed with reed plants (Imperata cylindrica) and other grass species.

\section{Settlement}

Areas around houses are generally planted with various species of plants with economic or aesthetic value. These are generally small areas of vegetation measuring less than 
$150 \mathrm{~m}^{2}$. Species of plants commonly found in settlement yards include banana (Musa paradisiaca), coffee (Coffea spp.), jackfruit (Artocarpus heterophylla), African umbrella tree (Maesopsis eminii), clove (Eugenia aromatica), avocado (Persea americana) and bamboo (Bambusa spp.).

\section{Fields, fishponds, and rice fields}

Fish ponds are used to grow fish such as tilapia (Tilapia mozambica). Fishponds are generally found in areas of land by the river where natural springs emerge. In addition to aquaculture, fishponds are alternately used for growing rice. Generally, rice is grown in wet paddy systems using high-yielding varieties of rice, allowing 2 to 3 harvests per year. Surveys suggested that these environments are poor in native species

\section{Fauna}

In the area of direct impact of the UCPS hydropower project development (including quarry, roads, dams and transmission lines) 213 vertebrate species have been recorded, consisting of 36 species of mammals, 114 species of bird, 48 species of reptiles and amphibians, and 15 species of fish. Of the animals found so far in Cisokan, several mammals are of immediate global conservation concern (Table 1), with two species, the Javan Slow Loris and the Javan Leopard being considered Critically Endangered on the IUCN Red List of Threatened Species. This means that they are facing an extremely high risk of extinction in the wild. Their presence in Cisokan, and also their protected status in Indonesia, means that the utmost effort is required to ensure that during project development and implementation not a single one of these animals is negatively impacted through direct or indirect project interventions.

Although the densities of the species of highest conservation concern vary throughout the area, most species appear to be wide-spread. Depending on their ecological needs (as well as local threats such as hunting and collecting), species may occur in just one or two of the largest forest patches (for example, the Javan Gibbon), in most large forest patches (for example, the Javan Leaf Monkeys), or wide-ranging throughout the area with particular areas used as shelter (for example, the Javan Leopard) (see Figure 2).

It needs to be emphasized that so far most biodiversity survey efforts have been in the areas directly impacted by project development (access road, project infrastructure, and the two dam sites), with fewer surveys conducted in the broader watershed area. This gives a slightly biased view with more species records in the areas of highest survey effort. Overall it is possible to deduce, however, that any reasonable-size natural forest patch in the region will have at least some of the species of high conservation concern, and maintaining the ecological quality and integrity of any patches of natural (albeit degraded) forest should be a key objective of PLN's biodiversity program.

\section{Mammals}

The lower dam areas are richest in mammal species with 34 species so far detected, compared to 25 in the upper dam area, 6 in the quarry area, 11 in the access road area, and 1 species in the area earmarked for transmission line development. The habitat for various species of mammals, including several monkey species, Javan deer, gibbons, and leopard has been highly fragmented into a number of small forest patches and the populations of these species are in urgent need of forest cover expansion to meet their ecological needs (LIPI 2012). For example, the Critically Endangered Javan Leopard (Panthera pardus melas) needs access to dense vegetation with a continuous canopy as a place to hide, hunt or rest, and with access to prey populations and water. It also needs to be part of a contiguous population of leopards allowing gene flow and reproduction.

Table 1. Key target species for biodiversity management in Cisokan, Cianjur, West Java, Indonesia

\begin{tabular}{|c|c|c|c|}
\hline \multirow[b]{2}{*}{ Taxa } & \multirow[b]{2}{*}{ Local name/English name } & \multicolumn{2}{|c|}{ Status } \\
\hline & & $\begin{array}{l}\text { Protection status in } \\
\text { Indonesia }\end{array}$ & $\begin{array}{c}\text { IUCN Red List } \\
\text { category }\end{array}$ \\
\hline \multicolumn{4}{|l|}{ Artiodactyl } \\
\hline Tragulus javanicus (Osbeck, 1765) & Pelanduk kancil/Javan Mouse-Deer & $P$ & DD \\
\hline \multicolumn{4}{|l|}{ Carnivore } \\
\hline Aonyx cinerea (Illiger, 1815) & Sero ambrang/Small-clawed Otter & NP & VU \\
\hline Arctictis binturong (Raffles, 1821) & Binturung muntu/Binturong & NP & VU \\
\hline Prionailurus bengalensis (Kerr, 1792) & Meong congkok/Leopard Cat & $\mathrm{P}$ & $\mathrm{LC}$ \\
\hline Panthera pardus melas (Cuvier, 1809) & Macan tutul Jawa/Javan Leopard & $\mathrm{P}$ & $\mathrm{CR}$ \\
\hline \multicolumn{4}{|l|}{ Pholidota } \\
\hline Manis javanica (Desmarest, 1822) & Trenggiling/Pangolin & $P$ & $\mathrm{EN}$ \\
\hline \multicolumn{4}{|l|}{ Primate } \\
\hline Presbytis comata (Desmarest, 1822) & Lutung surili/Grizzled Leaf Monkey & $\mathrm{P}$ & EN \\
\hline Trachypithecus auratus (Geoffroy, 1812) & Lutung budeng/Javan Langur & $\mathrm{P}$ & VU \\
\hline Hylobates moloch ( Audebert, 1798) & Owa Jawa/Javan Gibbon & $\mathrm{P}$ & EN \\
\hline Nycticebus javanicus (Geoffroy, 1812) & Kukang/Javan Slow Loris & $\mathrm{P}$ & $\mathrm{CR}$ \\
\hline
\end{tabular}

Notes: DD: Data Deficient; LC: Least Concern; VU: Vulnerable; EN: Endangered; CR: Critically Endangered; P: Protected; NP: Not Protected 


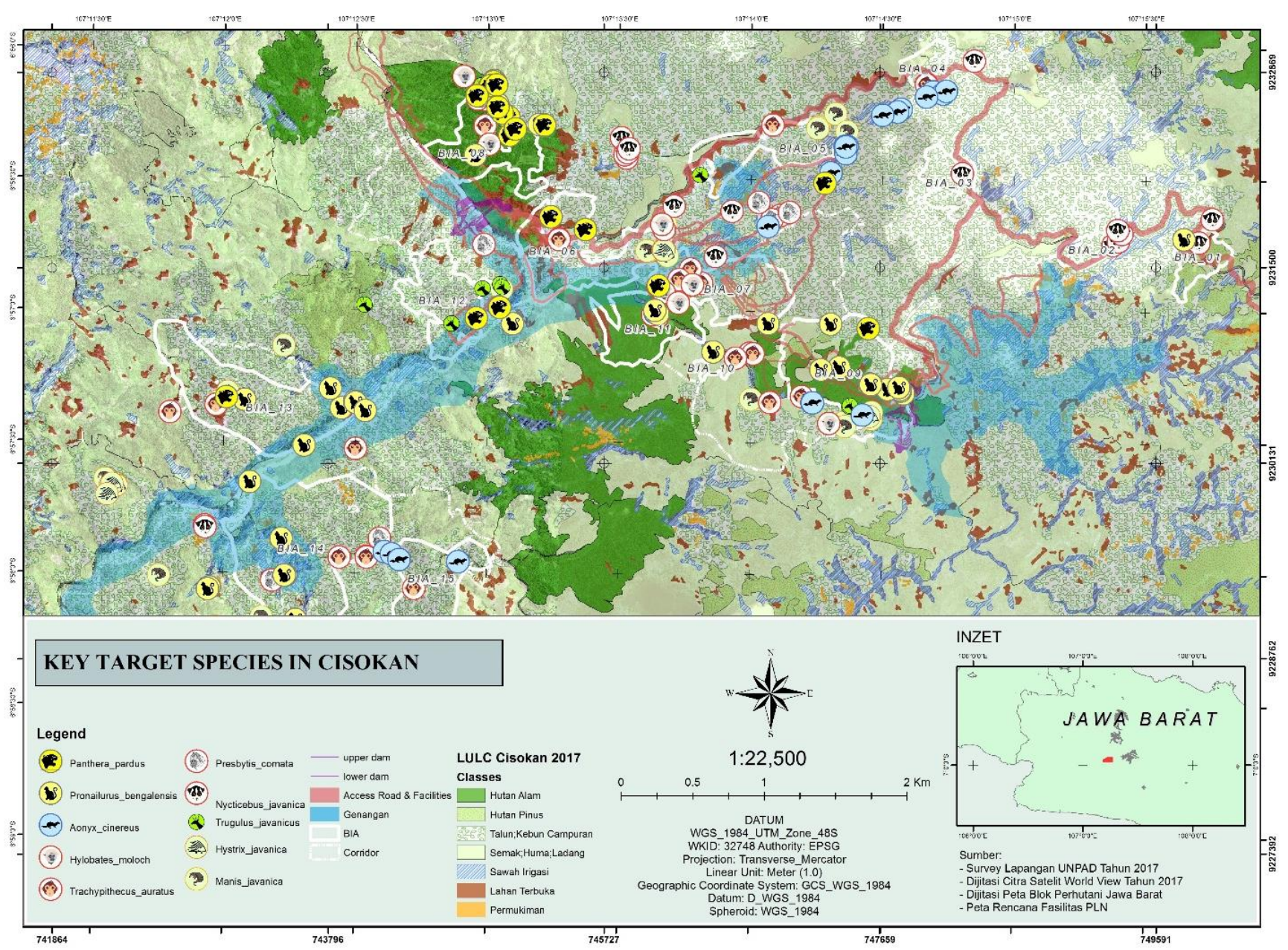

Figure 2. Selected species presence points in the UCPS area, Cianjur, West Java, Indonesia (in 2017)

Five species of primate occurred in the area, including the earlier-mentioned Javan Slow Loris (Nycticebus javanicus), the Endangered Javan Gibbon (Hylobates moloch), the Endangered Javan Leaf Monkey (Presbytis comata), the Vulnerable Javan Langur (Trachypithecus auratus), and Long-tailed Macaques (Macaca fascicularis). These species all occurred in small forest fragments. According to Withaningsih et al. (2018), Javan Slow Loris was found in Cipateungteung, Lembur Sawah, Cilengkong, Ciawitali, and Babakan Bandung hamlets. Ecologically they can cope with such degraded conditions, apart possibly from the gibbons which are quite fruit-dependent (and fruit availability tends to vary temporally). Leaf Monkeys and Langurs will come to the ground if needed and can cross a gap between forest patches. Gibbons and Slow Loris are, however, likely restricted to one forest patch, where their very small population size threatens their survival. The best primate habitats remain forest patches around the Japarana waterfall near the upper dam and the forest areas around the Curug Walet waterfall, Cimanggu, Cilengkong River, and the Gowek forest, all around the lower dam.

The Javan Leopard (Panthera pardus melas) is genetically and morphologically very distinct and there have been calls to assign it full species status (Meijaard 2004; Gippoliti and Meijaard 2007). The species is frequently persecuted in Java and under high threat. Ecologically, it can cope quite well with forest degradation. The existence of leopards in the Gowek and Pasir Nangka forest patches is evidenced by various animal signs and recorded by camera traps. In addition, interviews with residents of the Babakan Bandung village and other villages indicated some problems of leopards' feeding on people's dogs and goats (LIPI 2012). According to Shanida et al. (2018a), leopard was found in Pasir Nangka, Pasir Laja, Sarongge, Batu Nagok, Pasir Taman, Batununggul, Cilengkong, Cisuren, Cigintung, Cileungsing, Cipanas, and Pasir Bedil/Japarana. The other protected species, Leopard cat was found in Datarmala, Pasir Bedil, Cirumamis, Cilengkong, Batununggul, Pasir Taman, Cigintung, Ciawitali, and Sarongge (Shanida et al. 2018b).

Other mammal species of conservation interest that have so far been identified in the Cisokan area include the Endangered Pangolin (Manis javanica), a species which is highly sought after for the Chinese medicine trade. Pangolins have been recorded in Cisokan within the last 2 years, including in the Gowek forest, Curug Walet, Manggu, and the Hantar road area. According to 
Withaningsih et al. (2018), pangolin was found in Cigintung, Pasir Gagak, Batununggul, and Curug Walet through camera traps. In July 2013, a case of poaching by local communities was reported with the animal sold for USD 30/kg. There is apparently high market demand for pangolins in the nearby towns of Cianjur and Sukabumi. The Near Threatened Black Giant Squirrel (Ratufa bicolor) and the Vulnerable Small-clawed Otter (Aonyx cynerea) also occurred in various parts of the Cisokan area, but, like the primates and leopard, they were widely dispersed and affected by fragmentation and local hunting pressure. The last mammal of conservation interest is the Javan MouseDeer (Tragulus javanicus), a species considered DataDeficient by the IUCN because it is unclear whether one or two species occur in Java. Hunting by the local communities prior to the 1960 s has led to a major population decline, and the species is now locally very rare. In 2012, the presence of mouse-deer was reported along the Hantar road around NR 25 and in the Gowek secondary forest, Pelesiran, Cimanggu and Batu Bedil (LIPI 2012). Most IUCN-listed species in Cisokan are protected according to Indonesian law, which prohibits any activities that harm the animals.

\section{Reptiles and amphibians}

The surveys in UCPS have so far recorded 21 species of amphibians and 27 species of reptiles, of which two snakes (Python reticulatus and $P$. molurus) are protected in Indonesia. None of the reptiles and amphibians encountered so far in Cisokan are of global conservation concern.

\section{Birds}

In the project area, 114 species of birds have been recorded, 72 of which in the lower dam area and 43 in the upper dam area, reflecting the greater forest cover in the former area. Forest area in the lower and upper dam contains some typical forest bird species, such as Orangefronted Barbet (Megalaima armillaris), Blue-eared Barbet (Megalaima australis), Black-banded Barbet (Megalaima javenensis), Black Eagle (Ictinaetus malayensis), Changeable Hawk-Eagle (Spizaetus cirrhatus), and Banded Pitta (Pitta guajana). Of the 114 species of birds, 11 are endemic to the island of Java, and 18 are nationally protected by law. Two of the above-mentioned barbet species are listed as Near Threatened by the IUCN, but overall the area's avifauna is not rich in bird species of international conservation. This may be caused by high hunting pressure of sought-after cage birds. Bird poachers were frequently encountered during surveys in the area.

\section{Fishes}

Fifteen species of fish have so far been encountered in the Cisokan area (LIPI 2012). Java has some 135 species of freshwater fish, which indicates the impoverished nature of the local fish fauna. Fish species found in Cisokan are all very common in Java and are often used for consumption by local people. Eighty percent of the species of fish found in Cisokan is native to Java, with $20 \%$ having been introduced, including Poecilia reticulata, Xiphophorus helleri, and Aequidens rivulatus. Overall, the quality of the aquatic habitats is still good. However, some species of fish such as Rasbora lateristriata and Hemibagrus nemurus that are normally found in such upland rivers, have been difficult to obtain (LIPI 2012).

None of the fifteen fish species recorded in the UCPS area is protected. The low diversity of fish species is probably caused by the activities of people who take fish using insecticides (Potassium, Thiodan, and Takodan), especially in the dry season (LIPI 2012).

\section{Flora}

No plant species identified in Cisokan is internationally listed as threatened, either in earlier surveys (LIPI 2012; Rahmat 2009; ANDAL 2007) or during rapid assessments surveys in June and July 2013. One species is listed in CITES Appendix, which is the tree fern Cyathea contaminans. Surveys identified several species considered rare in Java, including Pangium edule, a tree with edible fruits, Syzygium polycephala, rosewood Albizia procera, Bischofia javanica, Castanopsis javanica, and Arenga pinnata.

\section{Main threats to biodiversity \\ Existing threats prior to project development}

Deforestation and forest degradation through agricultural conversion. The agricultural development, primarily land clearing, impacted mainly the vegetation. No clear information is available on the history of land clearing, but there have likely been long-term human impacts on the original forest vegetation. A vegetation map from 1950 shows the uplands around Cisokan still covered with natural forest (Figure 3), with lower-lying areas was likely used for community agriculture. A 1919 photo from the Cisokan River area where the project is being developed shows mostly forested slopes, and also provides an idea of what the original vegetation looked like, in case reestablishing this original vegetation cover becomes a longer-term management objective. Even then there would likely have been some level of degradation of forested slope areas. Since about the 1960s, deforestation has significantly increased to the present point at which there are few remaining forest areas larger than a few dozen hectares.

Community land use has significantly impacted areas of previously forested slopes, mainly through slash-and-burn activities, with more permanent rice agriculture focused on the valley floors adjacent to the rivers. Cutting and burning of the vegetation usually result in not only the clearing of undergrowth but also forest trees, such as teak and pine. The nature of this shifting type of agriculture has resulted in a mosaic of forest patches-with the best forests often remain undisturbed on the steepest slopes least suitable for cultivation - and a matrix of more or less degraded forest and scrub areas, as well as grasslands. Some dry rice is also grown on the slopes and some steep areas are planted with lemongrass crops that grow well there. These community activities have had a major impact also on production forest areas (under state-owned forest company-Perhutanimanagement), and it is very hard to find a good pine tree now. 
Hunting and collecting of wildlife. Communities also pose a threat to local biodiversity because of hunting and collecting activities, which are legal, unless involving protected species, and can be hard to control, especially if the monetary value of species is high. Such commercial collecting primarily targets species such as pangolin and a wide range of bird species which are popular in the pet trade. Pet trade also affects some of the primates, with especially Slow Loris being in high demand in South East Asian animal markets, but also other species such as leaf monkeys are traded.

Wildlife conflict also poses a threat to species, especially pigs and deer feeding on agricultural crops. Communities consider these species pests and hunt or trap them when they can. Indirectly this also affects predators such as Javan Leopard, for the disappearance of its prey forces it on occasions to feed on dogs or other domestic animals, with potentially fatal consequences for the leopard.

Communities hold some traditional beliefs regarding the protection of some species or forest areas, but considering the rapid decline in forest cover over the past 6 decades and generally declining wildlife values, these positive forces have not been able to effectively counteract threats. Still, long-term biodiversity management in the area should make use of traditional belief systems that help protect wildlife where possible.

\section{Direct and Indirect Threats from the UCPS}

Land clearing and inundation. Within the area directly impacted by hydropower infrastructure construction (access road, reservoir area, dams, switchyard, transmission lines, temporary access roads, spoil banks, etc.), land clearing and/or inundation in those parts that are still forested will add to pressure on remaining forest patches, and will result in a net loss of forest area in the larger landscape unless reforestation activities are undertaken.

Land clearing along the access and other roads will impact an area of 27-km-long and $40 \mathrm{~m}$-wide (an area of approximately $107 \mathrm{ha}$ ), but impacts on biodiversity differ among road segments depending on the type of vegetation the road dissects. Land clearing on a particular road will primarily occur in the settlement, yard, mixed garden, talun, rice fields, and fish pond land cover types. The other road section towards the lower and upper dam will primarily cross the production forest and remaining natural forests vegetation types, including six BiodiversityImportant Areas (BIAs).

Plant species that will be lost due to understory clearing, tree felling or brush cutting on a particular road will primarily include cultivated plant species with economic value to the communities. This includes sugar palm (Arenga pinnata), bamboo (Bambusa apus) and coffee (Coffea arabica), the loss of which can affect people's income. The clearing could also affect plant species that are rarely found in West Java such as kepel (Stelechocarpus burahol), menteng (Bacaurea racemosa), putat (Planchonia valida), and Litsea resinosa.

Further impacts from land clearing and associated damages include a decrease in the complexity of the vertical stratification and reduced horizontal canopy connectivity, impeding wildlife movement. Canopy impacts and forest fragmentation also increase edge effects and induce micro-climatic changes within the remaining forests. The project footprint associated with the upper and lower dam inundation areas of 105 ha and 357 ha respectively will create barriers to wildlife movements, as well as the loss of some habitat from the BIAs.

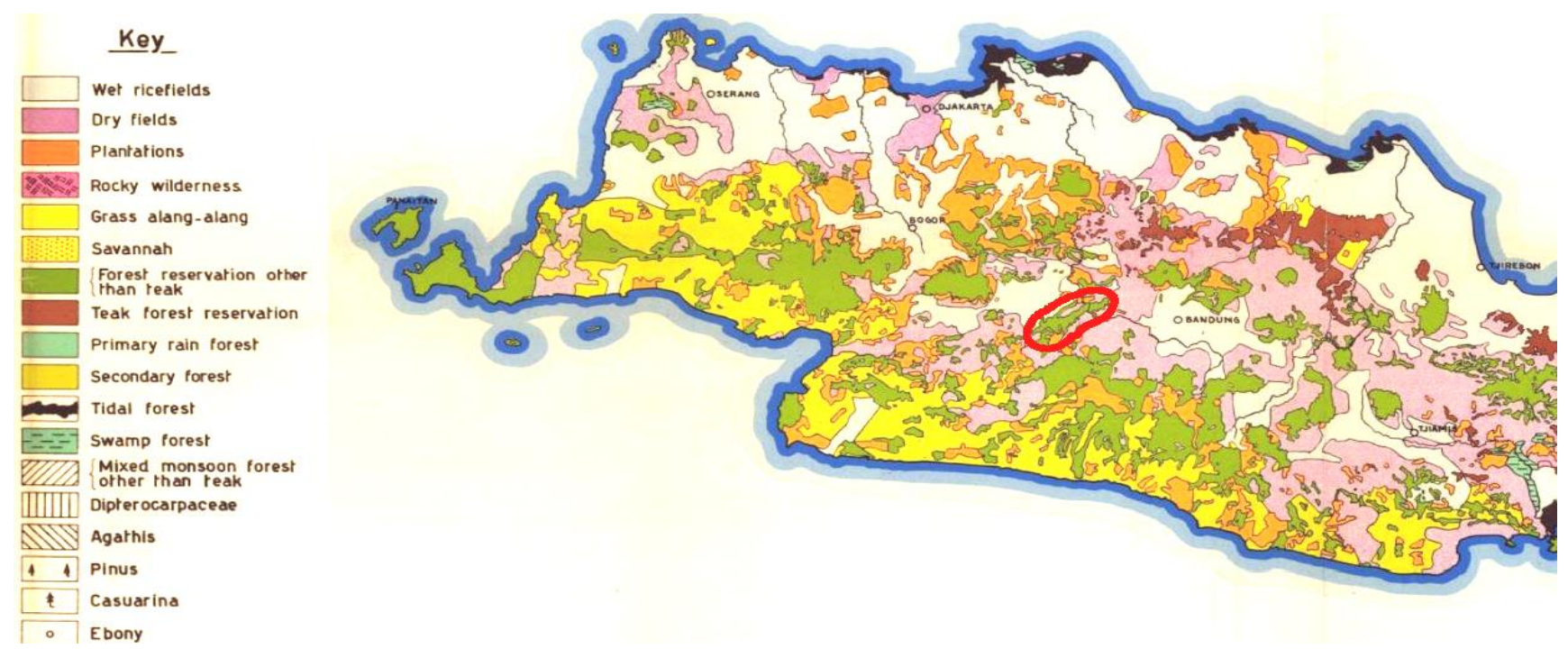

Figure 3. Vegetation map of West Java, Indonesia, 1950. (Composed by the Planning Department of the Forest Service, under the supervision of J.W. Hannibal.) The area indicated by the red line is the Cisokan watershed, which was still indicated as natural forest surrounded by dry fields in 1950 (Meijaard and Pene 2014) 
Induced development from improved access. Construction of the access road to the project area will facilitate commodity transportation produced by shifting cultivation and farms to nearby cities and towns, increasing the net revenues that can be obtained from agriculture. This could increase the demand for shifting cultivation areas increasing the pressure on remaining forests. Improved access may also attract immigrants who seek a living in the area, increasing the pressure on scarce land and wildlife resources. Unless managed carefully, these changes will increase the damage on vegetation and threaten the existing biodiversity in the UCPS hydropower area. Furthermore, during forest clearing, the ease of access would potentially facilitate the transportation of illegal timber.

Hunting and collection by workers. A final threat related to land clearing during the construction phase comes from project workers who could engage in wildlife poaching and collection of timber from forests for construction or other purposes. This primarily concerns areas where construction occurs adjacent to or in natural forest areas. These workers also increase the risk of fires that, especially during the dry season, could go out of control and affect larger forest areas.

\section{Project context of the BMP}

This BMP is one of the sub-plans of the UCPS hydropower Environmental Management Plan and will be implemented by PLN's UCPS Project Team (supported by the Environmental Division in the Bandung Office). It covers the management of endangered species and secondary forest habitats within the project area of the Upper Cisokan area. The Plan documents an adaptive management approach to biodiversity conservation and protection, which includes a phased approach to: (i) evaluating the sustainability and vulnerability of the remnant habitat and its inhabitants, (ii) identifying suitable management methods to achieve self-sustaining habitats and populations of endangered species, (iii) implementing appropriate management methods, particularly during construction and pre-inundation (with a monitoring and review process to continue appropriate management during the inundation and operational phases), (iv) developing the first steps of an ICM (Integrated Catchment Management) program, with a view to developing a 'Green Dam'- a hydropower project that will enhance the host environment by managing the catchment landscape for multiple outcomes (economic, biodiversity, social).

\section{BMP Strategy and Action Plan}

\section{BMP Project Area and Biodiversity-Important Areas}

Based on the biodiversity studies, the identification of species of main conservation concern, and the presence and size of good habitat, Biodiversity-Important Areas (BIAs) were mapped (Figure 4). These initial studies have so far identified 15 BIAs, with a total area of about 425 ha. The Convention on Biological Diversity recognizes protected areas as a tool for in situ conservation that must be seen in conjunction with other relevant provisions of the Convention. Convention on Biological Diversity defines protected area as "a geographically defined area which is designated or regulated and managed to achieve specific conservation objectives". Accordingly, national protected area systems have been developed and maintained as key elements of national strategies to conserve biological diversity (Secretariat of the Convention on Biological Diversity 2004).

According to Brown and Lynn (2009), prioritization of species should be based on species conservation status, i.e., the highest priority is assigned to taxa listed as critically endangered, followed by endangered and vulnerable. Threats and the priority species affected by each threat were systematically identified using existing information, expert knowledge, and community consultation. The geographical distribution of priority species and their associated threats were used to identify areas of particular conservation significance where threats are causing the most harm to biodiversity. The broader scope of multispecies plans allows resources to be sought and prioritized across a wider range of goals and programs than that of single-species plans. This minimizes potential conflicts that may arise among plans that address species individually. By focusing on management of threatening processes, a multispecies plan provides benefits to a broad range of biodiversity, including species that may not currently be threatened (Brown and Lynn 2009).

Some of these BIAs overlap with the project footprint, for example, in the inundation areas. Protecting wildlife and minimizing habitat loss in these BIAs are the main objectives of the construction-related management strategies, ensuring the long-term viability of the populations of the threatened species related to the strategies of landscapelevel management under the ICM program.

The BIAs was identified on the basis of the presence of threatened species (Table 2) and the ecological integrity of the vegetation. All are relatively small and more or less degraded, and their expansion and environmental enrichment are important to ensure that the existing wildlife populations stand a chance to survive. At the moment, PLN does not have the legal authority to enforce any recommendations regarding protections of these BIAs, first, because most of the BIAs are on state forest land where Perhutani determines management, and, second, because community has implemented long-term informal management of many of the BIAs. This makes it difficult at the moment to restrict access to BIAs, prohibit hunting, tree cutting or collecting of non-timber forest products. Effective protection of wildlife in the BIAs and proposed connecting areas among BIAs requires significant buying from local communities as well as Perhutani, making engagement of these stakeholders a key objective for the ICM (Integrated Catchment Management) program.

Similar to BMP conducted by the Lechmere-Oertel (2010) Hogsback Stewardship Area (Eastern Cape, South Africa), this BMP needs to be carried out with a protected environmental declaration with an effort to protect the area if the area is sensitive to development due to biodiversity, natural characteristics, and scientific, cultural, historical, archeological or geological values. 


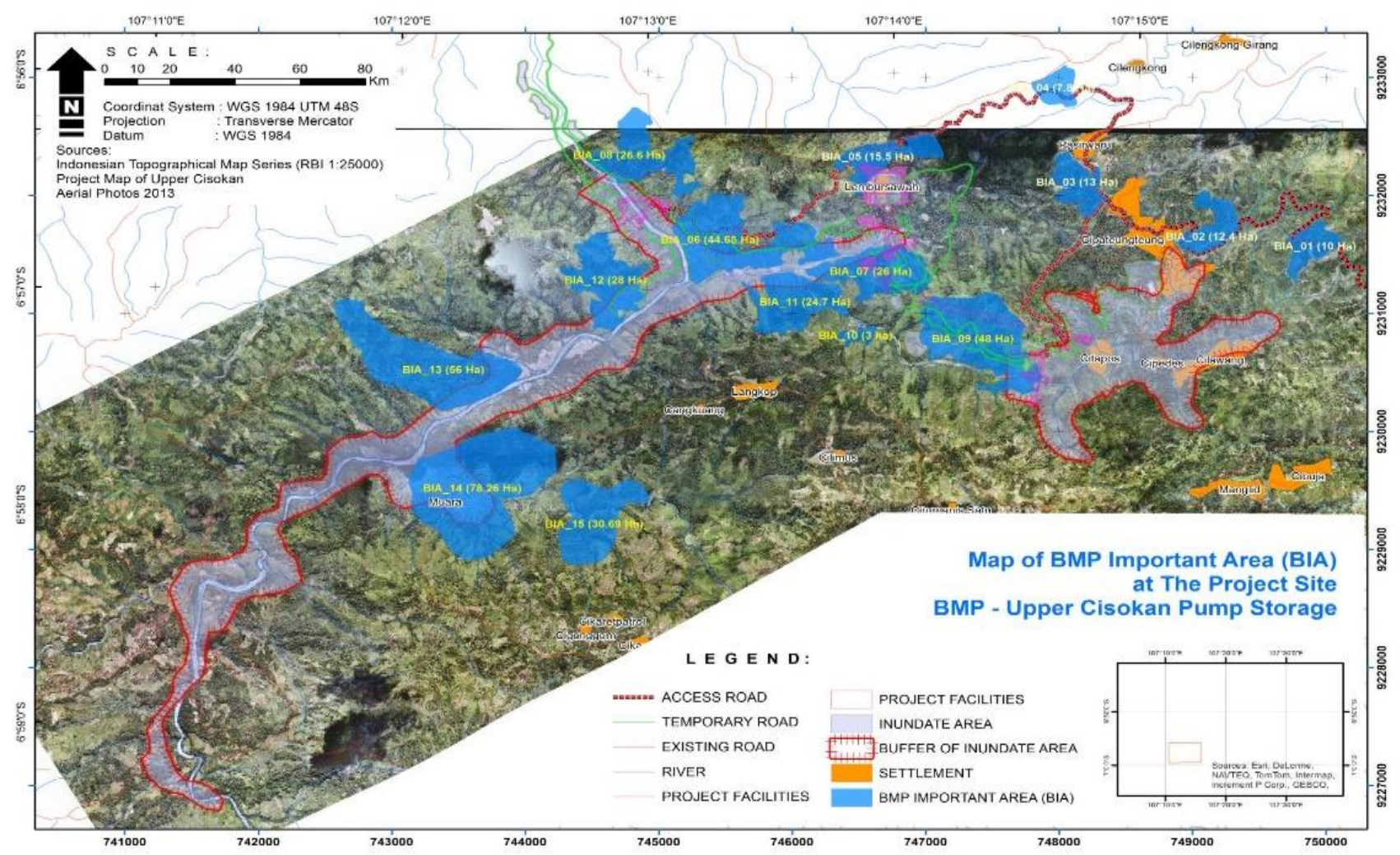

Figure 4. Distribution of Biodiversity Important Areas in the Cisokan area, Cianjur, West Java, Indonesia (in 2014)

\section{Biodiversity management strategy}

The first step in protected area management is to determine objectives at both the system and site levels; these objectives determine who gets what benefits, and pays what costs at what scale. This is a political process that should involve dialogue with the key stakeholders, including landowners, scientists, local communities, NGOs, and the private sector. Because different objectives involve trade-offs in terms of the distribution of costs and benefits, they need to be made explicit in management terms. Further, many of the public good benefits of protected areas provide significant advantages for the global community, including conservation of biodiversity, sequestration of carbon, and the results of ecosystem research (Secretariat of the Convention on Biological Diversity 2004).

\section{Objective 1: Minimization of habitat gap and habitat loss}

Habitat gap and habitat loss in Cisokan are caused by infrastructure construction, cut and fill during the construction. Minimization of habitat gap and habitat loss is carried out to avoid disruption of animal movements and reduction of the area of animal habitat. To minimize the habitat gap, it is necessary that clearing of vegetation in certain areas should be carried out according to the land clearing SOP. To avoid disruption of animal movement, PLN should make animal channels as tracks of small mammals, put tree trunks for crossing animals on cliff lands, and bridging ropes for arboreal mammals. In addition, PLN should put signs for the prohibition of access roads and inspection outside of project activities.

\section{Objective 2: Expansion and enrichment of habitats}

This objective aims to replace and simultaneously reexpand disturbed (shrinking) wildlife habitat due to land clearing for the construction. This is carried out to ensure the availability and quality of animal habitats. Expansion and enrichment of habitat are carried out through three approaches, namely environmental improvement by land engineering (soil and water conservation), revegetation, and/or using a combination of these two methods. According to RTA (Roads and Traffic Authority) Environment Branch (2011), re-establishment of native vegetation can be achieved through revegetation. Revegetation is the process of replanting or re-establishing the native vegetation that has been disturbed or removed.

Improving the quality of animal habitat can be carried out by installing nest boxes. According to Franks and Franks (2006), approximately $20 \%$ of native fauna species rely on tree hollows for roosting, nesting and breeding. Nest boxes can be used to provide supplementary breeding habitat and shelter for hollow-dependent animals where hollows have been removed. When designed, built, installed and monitored correctly nest boxes can provide an alternative to natural animal habitat. The nest box strategy, including the design, placement, and monitoring, should be developed in consultation with an ecologist. It is recommended that an ecologist is on site during the installation of nest boxes. 
Table 2. Important wildlife in BIAs in Cisokan, Cianjur, West Java, Indonesia

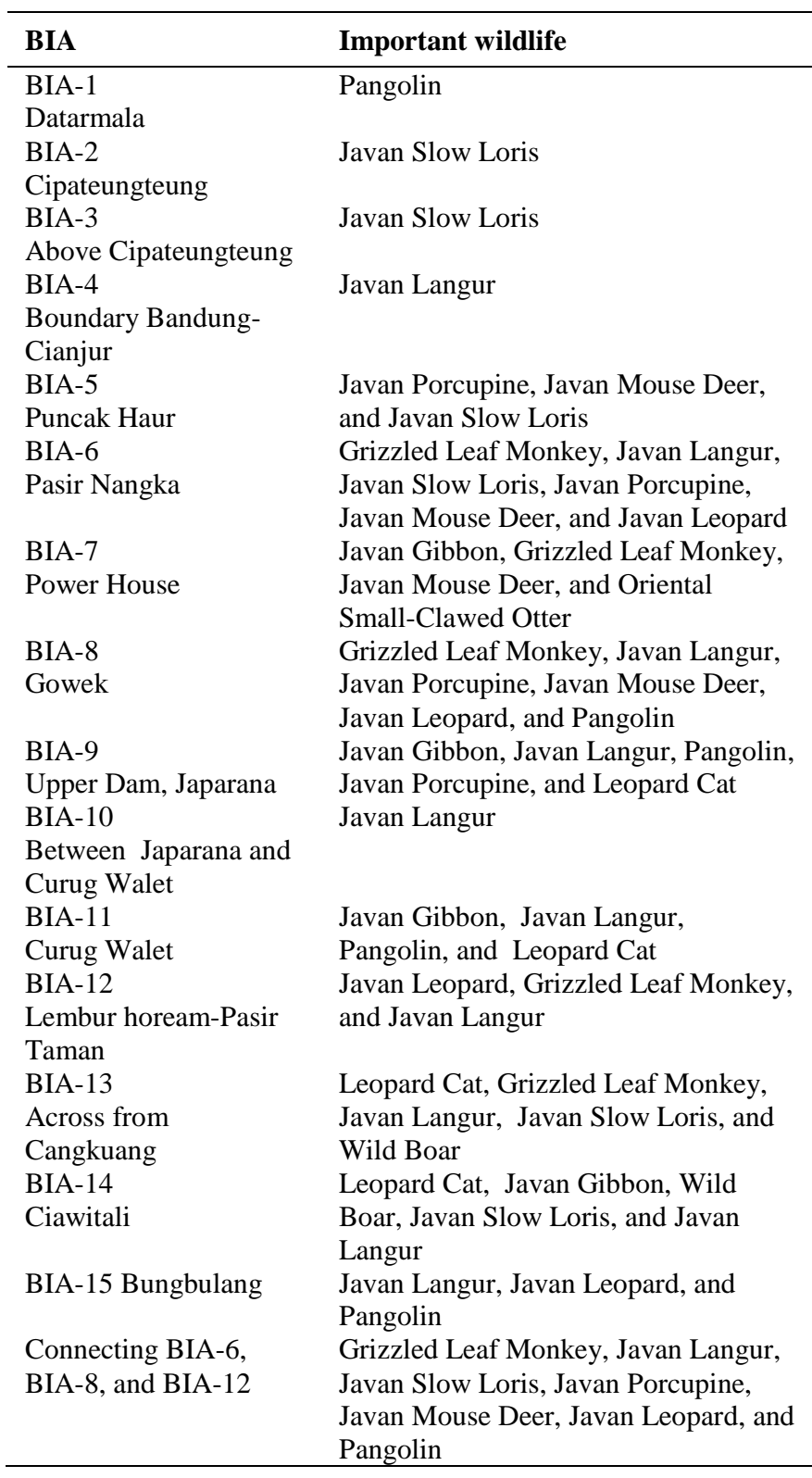

\section{Objective 3: Corridor making}

This objective aims to minimize the disruption of wildlife crossing places due to habitat gaps. This is carried out by providing animal crossings to reduce barriers to the movement of animals in their home range. Corridors are divided into two categories, namely physical (artificial) corridors and green corridors or vegetative corridors. The making of corridors is based on the loss of vegetation and the opening of land due to land clearing activities in planned areas for access roads, dam, and other main buildings. Corridors serve primarily to maintain the viability of isolated populations while ensuring ecosystem functionality and harmonizing conservation and development needs (Beier and Noss 1998 in Rovero and Trevor 2012). According to Hilty and Merenlender (2004) in Green et al. (2018), the width of the corridor is known to influence corridor use with wider corridors being preferred.

\section{Objective 4: Protection of natural forests/remnant forest}

This objective aims to avoid the damage and shrinkage of the remaining natural forest around the UCPS hydropower project area due to land clearing. This is carried out by maintaining the remaining natural forest in the area around the UCPS hydropower project and the existence of old production forests and old agroforestry in the Perum Perhutani area. To protect the remnant forest, it is imperative to avoid land clearing and logging in certain area, to install signs that prohibit logging activities and encroachment, and to conduct socialization to the community in order to improve understanding of environmental preservation so that they do not encroach on the remaining natural forest.

\section{Objective 5: Controlling access}

This objective aims to prevent the potential for increased forest encroachment and poaching by the community. This is carried out with the construction of the guard posts for routine supervision on the access road that may increase human interaction with animals or wildlife habitat, and with the installation of information boards prohibiting unauthorized people to enter the area and hunting/collection of forest resources.

\section{Objective 6: Fire management}

This objective aims to prevent the activities of workers and community that have the potential to cause land/forest fires so that it can disrupt biodiversity. Project workers are prohibited to make fires outside of project interests such as cooking, smoking, burning garbage, or bonfires except in predetermined environments such as basecamp. To anticipate land/forest fires, a prevention team and fire department should be formed to anticipate land/forest fires. Information boards should also be made to prohibit smoking, and making fire, and socialization to the community should be conducted to improve understanding of environmental preservation.

Early warning systems that can detect fires (hot spots) based on satellite imagery and drought index can provide very important information for forest managers (Hoffmann et al. 1999). A number of early warning systems exist and are running well in Indonesia (Dennis 1999). Theoretically, the system can provide the information needed for forest managers for the reduction and handling of fire disasters, the construction of firebreaks to protect high-value resources, and provide up-to-date information on fires during critical fire situations (Meijaard et al. 2006).

Objective 7: Managing the impact of traffic on native fauna

This objective aims to ensure that project vehicle traffic activities do not disturb wildlife to prevent the occurrence of death of wild animals along the roads due to being hit by project vehicles. This is carried out by making animal channels, bridge ropes, animal shelter, and animal terrace as described before. In addition, traffic signs about animal crossing places and vehicle speed limit should be made, and socialization to the project driver and the community 
should be conducted. According to Collinson et al. (2019), a wildlife-warning sign depicting a snake and placed $100 \mathrm{~m}$ before the dummy snake was most effective at reducing collisions.

Roads and their associated users are the cause of many negative impacts on wildlife, such as landscape fragmentation (Trombulak and Frissell 2000; D'Amico et al. 2016), pollution (Rheindt 2003; van der Ree et al. 2011) and creating barriers for migration (Taylor and Goldingay 2004;D’Amico et al. 2016) and gene flow (Hels and Buchwald2001; Andrews and Gibbons 2005; Anderson et al. 2010). A further impact is wildlife-vehicle collisions (WVCs) (Forman et al.2003; Coffin 2007), resulting in an animal being injured or killed (roadkill).

Road networks are ever expanding and are an increasing threat within developing countries (Keshkamat et al. 2009; Collinson et al. 2015). However, much of the current literature is focussed on developed countries (Fahrig and Rytwinski 2009; Caro et al. 2014) and, even when focussed on developing countries, those studies are concentrated on roadkill occurring on national and regional roads (Coelho et al. 2008; Garriga et al. 2012). Although national parks and nature reserves are custodians of biodiversity, primarily intended to conserve animals, plants, and habitats, as well as biotic processes and functions, roadkill does occur and is of high concern. For example, in Spain, roadkill rates within protected areas are higher than outside due to the higher wildlife diversity and abundance in the former(Garriga et al. 2012).

\section{Objective 8: Clearing management}

This objective aims to ensure that land clearing activities are in accordance with the specifications or extent planned to prevent and/or minimize damage and shrinkage of vegetation as wildlife habitat. Land clearing activities must follow the SOPs for land clearing and for handling wildlife.

Handling of animals may be necessary when they are encountered on a project and need to be relocated or, if injured, taken to a vet or wildlife carer. The careful handling of animals is essential to minimize stress or further injury on the animals, to prevent the spread of diseases and to avoid injury to the animal handlers. Animals should only be handled when absolutely necessary. It is preferable to avoid animal handling unless the life of the animals is at risk. Animal handling should be undertaken either by a licensed animal ecologist or wildlife carers (RTA Environment Branch 2011).

Clearing of land associated with the construction and maintenance works results in the loss of habitat of flora and fauna. Impacts on native flora and fauna, including threatened species, can be minimized by conducting the pre-clearing process before land clearing. The pre-clearing process provides a final check for any threatened species of plants and animals that may have moved into the area since the undertaking of previous surveys. This is particularly important where the season or prevailing weather conditions influence whether a species is found in an area (RTA Environment Branch 2011).
Clearing of vegetation and removal of bushrock has the potential to displace, injure or kill native flora and fauna, including threatened species. Nocturnal animals that shelter in tree hollows during the day and cryptic plant species (such as underground orchids) are at greatest risk during these activities. Wood and dead trees provide essential habitat for a wide range of native fauna and are important to the functioning of many ecosystems (RTA (Roads and Traffic Authority) Environment Branch 2011).

Bushrock is loose rock found on rock or soil surfaces. Many animal species use bushrock for shelter and to hide from predators, find food, avoid extreme weather and escape bush fires. Bushrock removal results in disturbance and removal of habitat for native fauna and flora that grow in rocky areas. Numerous threatened species are identified as being adversely affected by bushrock removal (e.g reptiles and frogs). Woody debris is defined as pieces of wood at least $100 \mathrm{~mm}$ in diameter and at least $500 \mathrm{~mm}$ long (Gibbons et al. 2005 in RTA (Roads and Traffic Authority) Environment Branch 2011). Sometimes woody debris and bushrock need to be removed from a site. When this occurs, consideration should be given to find suitable locations for re-use of this important habitat feature in nearby areas.

\section{Objective 9: Human-wildlife conflict management}

This objective aims to minimize conflicts between humans and wildlife and disruption of human activities on wildlife. The land clearing should be done in accordance with the established SOP in order to maintain healthy and safe environment. In addition, socialization should be done to improve the understanding of biodiversity to all stakeholders that are working in the UCPS hydropower area, including communities around it.

Conflict arises due to the difference in the socioeconomic interests of the community and the use of natural resources, especially forests, which are providers of environmental services. Therefore, conflict prevention and control is the responsibility of all parties, namely local governments (Forestry, Agriculture, Animal Husbandry, Plantation, Environment, Mining, Social Affairs, and Regional Natural Disaster Management Coordination Offices), security forces (Police and TNI), business world, land users on a wide scale such as extractive industries, community leaders (religious, cultural and informal), as well as other related parties such as village government and concession holders (Priatna et al. 2012).

\section{Objective 10: Minimizing impacts to biodiversity particularly threatened species}

This objective aims to minimize the impact on biodiversity, especially endangered species and protected by law. The recommendation suggested in the BMP document, including the standard procedure should be implemented. Socialization and counseling to all workers regarding laws and regulations about protected animals should be done, and both PLN and contractor should report various events related to human-animal interactions. 
Objective 11: Integrating management with adjoining land managers (PLN, Perhutani, and the community)

This objective aims to improve coordination/ cooperation between PLN, Perum Perhutani, and the community regarding land management to improve habitat quality. This is carried out by harmonizing collaborative activities of various parties (PLN, Perhutani, and the Community) in managing the UCPS and the surrounding area to optimize the protection of habitats and populations of animals, including paying attention to the interest of the community and other related parties.

Objective 12: Strengthening capacities for integrating and institutionalizing biodiversity conservation and management

This objective aims to establish and strengthen the institutional capacity of integrated and collaborative biodiversity conservation managers among the community, PT PLN, Perum Perhutani, BKSDA (Nature Conservation Agency), and other institutions. This is carried out to ensure that the management of biodiversity works well and at the same time provides benefits for various parties, especially improving the lives of the local community.

According to Pittock (2010), as the growth in new hydropower projects has moved to countries with emerging economies, many of the solutions for less-damaging infrastructure development must largely be found in these nations by strengthening the capacities and standards of their government, industry, academic and non-government sectors.

Objective 13: Biodiversity awareness, communication, and education

Increasing the knowledge and awareness of UCPS managers (PT PLN), contractors and communities in managing biodiversity are carried out to suppress the decline in wildlife populations and habitat damage in the UCPS hydropower area. In addition, this objective will increase the participation of PLN, contractors, and communities in managing biodiversity. To carry out this objective, PLN establishes a division that can involve the role and participation of the community and initiate the establishment of collaborative institutions in managing biodiversity.

\section{Objective 14: Value-added products and alternative sustainable livelihood development for bio-resource dependent communities}

This objective aims to increase people's income with activities that are in line with the principles of biodiversity conservation. Increased income of the community in the UCPS area is expected to reduce the pressure on the land, reduce forest encroachment, and stop hunting economically valuable animals. This is carried out by identification of economic potential and development of economic activities based on local natural resources. In conclusion, Upper Cisokan Pumped Storage (UCPS) will be built without sacrificing biodiversity of the area. This is done with the maintenance of the habitat of flora and fauna, the minimization of the threats to them and, at the same time, the improvement of the local communities' income.

\section{ACKNOWLEDGEMENTS}

Acknowledgements were given to Centre Environment Sustainability Science Padjadjaran University, Erri Noviar Megantara Academic Leadership Grant Padjadjaran University, Indonesia 2016-2017 who have supported this research, Erik Meijaard, Pene Ferguson, and the research team of BMP (Biodiversity Management Plan) 2017.

\section{REFERENCES}

ANDAL-PT. PLN. 2007. PLTA Upper Cisokan Pumped Storage in West Java. PT PLN. Bandung. [Indonesian]

Anderson CD, BK Epperson, MJ Fortin, R Holderegger, Patrick MAJ, Michael SR, Kim TS, Stephen S. 2010. Considering spatial and temporal scale in landscape-genetic studies of gene flow. Mol Ecol 19: 3565-3575.

Andrews KM, JW Gibbons. 2005. How do highways influence snake movement? behavioral responses to roads and vehicles. Copeia 4 , 772-782.

Ardhian D, Paul MG, and Arief T. 2014. Conservation program management guide based on the ecosystem approach. Penabulu Alliance, Jakarta.

Atmoko SSU, MA Rifqi, Gonda Nisam. 2012. The field guide of introducing of mammals and birds protected in Sumatera and Kalimantan. FORINA and USAID.D, Bogor.

Australian Government. 2016. Biodiversity management, leading practice sustainability development program for the mining industry. Attorney-General's Department, Robert Garran Offices, National Circuit, Canberra.

BHP Billiton. 2017. Regional land and biodiversity management plan. Western Australian Iron Ore. BHP Billiton, Australia.

Boiral O, Heras-Saizarbitoria, Brotherton MC. 2019. Improving corporate biodiversity management through employee involvement. Business Strat Environ. DOI: 10.1002/bse.2273.

Brown D, Lynn Baker. 2009. The Lord Howe Island Biodiversity Management plan: An Integrated Approach to Recovery Planning. Ecol Manag Restor. DOI: 10.1111/j.1442-8903.2009.0049.x.

Caro T, Dobson A, Marshall AJ, Peres CA. 2014. Compromise solutions between conservation and road building in the tropics. Curr Biol. 24. 722-R725.

Coelho IP, Kindel A, Coelho AVP. 2008. Roadkills of vertebrate species on two highways through the Atlantic Forest Biosphere Reserve, Southern Brazil. Eur J Wildl Res 54. 589-699.

Coffin AW. 2007. From roadkill to road ecology: A review of the ecological effects of roads. J Transp Geogr 15. 396-406.

Collinson WJ, Marneweck C, Davies-Mostert HT. 2019. Protecting the protected: reducing wildlife roadkill in protected areas. Anim Conserv. DOI: 10.1111/acv.12481. ISSN 1367-9430.

Collinson WJ, Parker DM, Bernard RTF, et al. 2015. An inventory of vertebrate roadkill in the Greater Mapungubwe Transfrontier Conservation Area, South Africa. Afr. J. Wildl. Res. 45. 301-311.

D’Amico M, Periquet S, Roman J, Revilla E. 2016. Road avoidance responses determine the impact of heterogeneous road networks at a regional scale. J. Appl.Ecol. 53. 181-190.

Dennis RA. 1999. A Review of Fire Projects in Indonesia 1982-1998. CIFOR, Bogor.

Dittmar M. 2014. Development towards sustainability: How to judge past and proposed policies?. Sci Total Environ 472: 282-288.

Fahrig L, T Rytwinski. 2009. Effects of roads on animal abundance: An empirical review and synthesis. Ecol Soc 14: 1-20.

Francis. 2001. A Photographic guide to mammals of South-East Asia: including Thailand, Malaysia, Singapore, Myanmar, Laos, Vietnam, Cambodia, Java, Sumatra, Bali, and Borneo. Ralph Curtis Publishing, Philadelphia. 
Forman R, Daniel S, John AB, Anthony C. 2003. Road Ecology: Science and Solutions. Island Press. Washington, DC.

Franks A, Franks S. 2006. Nest Boxes ForWildlife: A Practical Guide. Blooming Books, Melbourne.

Garriga N, Santos X, Montori A, et al. 2012. Are protected areas truly protected? The impact of road traffic on vertebrate fauna. Biodivers. Conserv 21. 2761-2774.

Gidda SB, Kalemani J M. 2004. Protected Areas in The Convention on Biological Diversity. In: Secretariat of the Convention on Biological Diversity. 2004. Biodiversity issues for consideration in the planning, establishment and management of protected area sites and networks. Secretariat of the Convention on Biological Diversity, Montreal.

Gippoliti S, Meijaard E. 2007. Taxonomic uniqueness of the Javan Leopard; an opportunity for zoos to save it. Bijdragen Tot de Dierkunde 76: 55-57.

Green SE, Zeke D, Timothy K, CP Doncaster. 2018. Do wildlife corridors link or extend habitat? Insights from elephant use of a Kenyan Wildlife Corridor. Afr J Ecol 5 (6): 860-871.

Hels T, Erik B. 2001. The effect of road kills on amphibian populations Biol Conserv 99: 331-340.

Hoffmann AA, Hinrichs A, Siegert F. 1999. Fire Damage in Eas Kalimantan in 1997/98 Related to Land Use and Vegetation Classes: Satellite Radar Inventory Results and Proposal for Further Actions. IFFM-SFMP Report No.1a. MOFEC, GTZ and KfW. Samarinda East Kalimantan.

Keshkamat SS, Looijen JM, Zuidgeest MHP. 2009. The formulation and evaluation of transport route planning alternatives: A spatial decision support system for the Via Baltica project, Poland. J. Transp. Geogr. 17. 54-64.

Lechmere-Oertel R. 2010. Biodiversity management plan for the Hogsback Stewardship Area (Eastern Cape, South Africa). Technical Report. Grassland and Amathole Forest Company, Stutterheim.

LIPI. 2012. A Study on the Flora and Fauna in the Project Area of HEPP Upper Cisokan Pumped Storage West Java. LIPI. Bogor. [Indonesian]

LPPM-PPSDAL UNPAD. 2014. Biodiversity Management Plan Upper Cisokan Pumped Storage Report. PT PLN (Persero) and LPPMPPSDAL Universitas Padjadjaran. Bandung. [Indonesian]

Meijaard E, Ferguson P. 2014. Biodiversity management plan upper Cisokan pumped storage. Technical report. PT PLN (Persero) Development Master Unit-UIP VI and Padjadjaran University.

Meijaard E, Douglas S, Robert N, et al. 2006. Life after Logging: Reconciling Wildlife Conservation and Production Forestry in Indonesia Borneo. CIFOR. Bogor.

Meijaard E. 2004. The biogeographic history of the Javan Leopard Panthera pardus based on a craniometric analysis. J Mammal 85 302-310.

Newbold T, Hudson LN, Arnel AP, Contu S, de Palma A, Ferrier S, Hill SL, Hoskin AJ, Lysenko I, Phillips HR. 2016. Has land use pushed terrestrial biodiversity beyond the planetary boundary? A global assessment. Science 353 (6296): 288-291.

Newing H, Eagle CM, Puri RK. 2011. Conducting research in conservation: A social science perspective., Routledge, London.

Payne J, and Francis CM. 20020. The field guide of mammalian in Kalimantan, Sabah, Sarawak, and Brunei Darussalam. Wildlife Conservation Society, Bogor.
Pittock Jamie. 2010. Viewpoint-better management of hydropower in an era of climate change. Water Alternat 3 (2): 444-452.

PLN. 2011. Upper Cisokan Pumped Storage Hydro Electric Power Plant (1040 MW) Consolidated Environmental Impact Assessment. PT. PLN Persero. Jakarta. [Indonesian]

PLN. 2012. Upper Cisokan Pumped Storage Hydro Electric Power Plant (1040 MW) Environmental Management Plan.PT. PLN Persero. Jakarta. [Indonesian]

Priatna D, Wilson N, Hariyo TW, et al. 2012. Practical Guidelines for Prevention and Control of Conflicts between Humans and Tigers. Ministry of Forestry, Republic of Indonesia. Jakarta. [Indonesian]

Rahmat A. 2009. UCPSS Biodiversity Survey. Upper Cisokan Pumped Storage Power Project (UCPSS) Additional Environmental Studies 2009. Bandung. [Indonesian]

Rheindt FE. 2003. The Impact of roads on birds: does song frequency play a role in determining susceptibility to noise pollution? Journal fur Ornithologie 144. 295-306.

Rovero F, Trevor J. 2012. Wildlife corridors in the Udzungwa Mountains of Tanzania. Ecological Restoration 30 (4): 282-285.

RTA (Roads and Traffic Authority) Environment Branch. 2011. Biodiversity Guidelines: Protecting and Managing Biodiversity on RTA (Roads and Traffic Authority) Projects. NSW Government and NGH Environmental Consultancy. New South Wales.

Secretariat of the Convention on Biological Diversity. 2004. Biodiversity Issues for Consideration in the Planning, Establishment, and Management of Protected Area Sites and Networks. Secretariat of the Convention on Biological Diversity. Montreal

Shanida SS, Partasasmita R, Husodo T, Parikesit, Megantara EN. 2018a Short Communication: The existence of Javan Leopard (Panthera pardus melas Cuvier, 1809) in the non-conservation forest areas of Cisokan, Cianjur, West Java, Indonesia. Biodiversitas 19 (1): 42-46.

Shanida SS, Partasasmita R, Husodo T, Parikesit, Megantara EN. 2018b. Short Communication: Javan Leopard Cat (Prionailurus bengalensis javanensis Desmarest, 1816) in the Cisokan non-conservation forest areas, Cianjur, West Java, Indonesia. Biodiversitas 19 (1): 37-41.

Taylor BD, Ross LG. 2004. Wildlife road-kills on three major roads in north-eastern New South Wales. Wildl. Res. 31. 83-91.

Trombulak SC, Christopher AF. 2000. Review of ecological effects of roads on terrestrial and aquatic communities. Conser Biol 14. 18-30.

van der Ree R, Jochen AGJ, EA van der Grift, Anthony PC. 2011. Effects of roads and traffic on wildlife populations and landscape function: Road ecology is moving toward larger scales. Ecol Soc 16. 1-9.

van Strien NJ. 1983. A guide to the tracks of mammals of Western Indonesia. School of Environmental Conservation Management, Ciawi, Bogor.

Withaningsih S, Fathimah N, Erri NM, Parikesit, and Teguh H. 2018. Nest existences and population of Pangolin (Manis javanica Desmarest, 1822) at the designated area of Cisokan Hydropower, West Java, Indonesia. Biodiversitas 19 (1): 153-162.

Withaningsih S, Parikesit, Astrini A, Ghitaswati P, Erri NM, and Teguh H. 2018. Distribution and habitat of Javan Slow Loris (Nycticebus javanicus E. Geoffroy, 1812) in non-conservation area. AIP Conf Proc. DOI: 1063/1.5061915. 